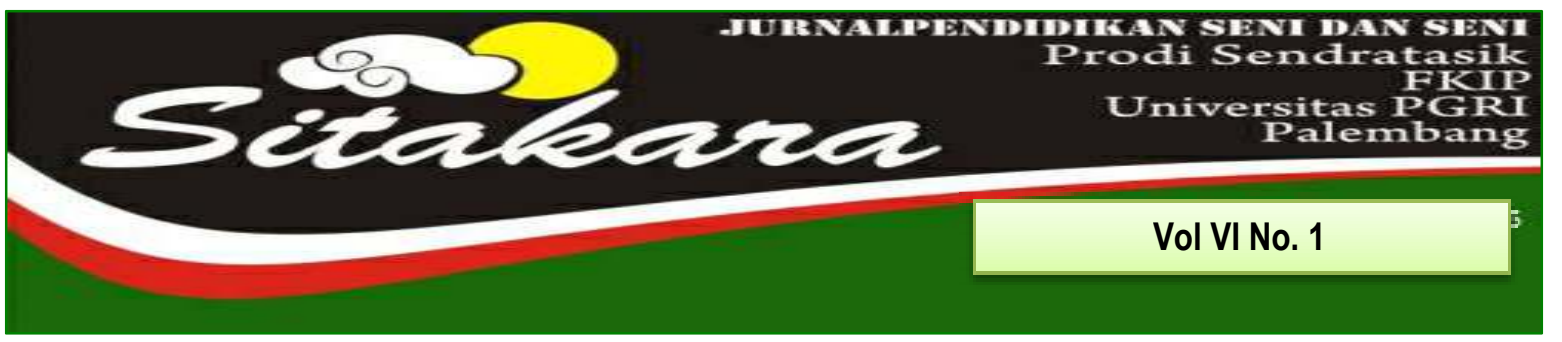

PERTUNJUKAN SOLIS MARIMBA DENGAN REPERTOAR THE VARIANTIONS ON THEME (FROM THE MALAY'S "PUCUK PISANG")

(Fery Herdianto)

BUKIT SIGUNTANG DALAM PENGEMBANGAN KONSEP RUANG KOREOGRAFI $\quad$ 13-26 LINGKUNGAN TARI

(Rully Rochayati, Eva Dina Chairunisa)

APLIKASI SIBELIUS SEBAGAI MEDIA PEMBELAJARAN DALAM MENULIS NOTASI MUSIK BERMAS

(Dedy Firmansyah \& Nugroho NAD)

PENGARUH MODEL PEMBELAJARAN EXPLICIT INSTRUCTION PADA 40-54 PEMBELAJARAN TARI DAERAH

(Treny Hera \& Efita Elvandari)

SIMBOLISASI ORNAMEN NAGA PADA PEMBATAS JALAN DI PALEMBANG (Decky Kunian \& A.Heryanto)

PENGARUH MODEL PEMBELAJARAN INSIDE-OUTSIDE-CIRCLE (IOC) TERHADAP WRITING SKILL DALAM TEKS MENULIS DRAMA DI SMP SETIA NEGARA PALEMBANG

(Sri Wahyu Indrawati \& Yuspar Uzer)

PEMANFAATAN TEKNOLOGI MULTIMEDIA DALAM PEMBELAJARAN MUSIK DI $79-87$ SMP N 1 PALEMBANG

(Novdaly Fillamenta \& Yuliza Aryani)

BENTUK PENYAJIAN ORKES GAMBUS SANGGAR MOZAIG PADA ACARA PERNIKAHAN ADAT ARAB PALEMBANG

(Auzy Madona Adoma)

PENINGKATAN KEMAMPUAN MEMBACA TEKS DRAMA DENGAN 100-111 MENGGUNAKAN METODE SPEED READING PADA PEMBELAJARAN BAHASA INDONESIA UNTUK SISWA SMPN 16 PALEMBANG (Wandiyo)

PELAKSANAAN EVALUASI PEMBELAJARAN SENI BUDAYA DI SMP 1 JEKULO 112-123 KUDUS PADA MASA PANDEMI COVID-19

M.Panji Wahyu Mukti \& Wahyu Lestari 
1. Naskah berbahasa Indonesia bertemakan Seni Budaya yang meliputi hasil penelitian pengajaran seni budaya, cabang seni, dan kebudayaan.

2. Naskah harus asli dan belum pernah dimuat dalam media lain. Naskah dapat berupa hasil penelitian perorangan atau kelompok.

3. Naskah ditulis dengan cara-cara yang sesuai dengan ketentuan penulisan artikel ilmiah menggunakan bahasa Indonesia yang baku, berupa ketikan, beserta soft line dalam CD-RW atau dengan mengirimkan email pada redaksi Jurnal SITARARA dengan alamat email: jurnalsitakarasendratasik@yahoo.com, spasi 1,5 jenis huruf Arrial Narrow ukuran 12, dengan panjang naskah antara 8-15 halaman pada kertas A4.

4. Artikel hasil penelitian memuat:

JUDUL

Nama Penulis

Abstrak

A. Pendahuluan

B. METODE PENELITIAN

C. HASIL DAN PEMBAHASAN

D. SIMPULAN
: XXX (HURUF KAPITAL)

: (disertai jabatan dan institusi)

: (Bahasa Indonesia yang memuat 100150 kata diikuti kata kunci, dengan jenis huruf Arrial Narrow dan ukuran huruf 11 spasi tunggal serta dicetak miring)

: (Memuat latar belakang masalah, tinjauan pustaka secara ringkas, masalah penelitian dan tujuan penelitian)

: (Berisi simpulan)

5. Artikel kajian konseptual memuat:

JUDUL

Nama Penulis

Abstrak

\section{: XXX (HURUF KAPITAL)}

: (disertai jabatan dan institusi)

: (Bahasa Indonesia yang memuat 100150 kata diikuti kata kunci, dengan jenis huruf Arrial Narrow dan ukuran huruf 11 serta dicetak miring)

PENDAHULUAN
: (Memuat latar belakang masalah, tinjauan pustaka secara ringkas, masalah penelitian dan tujuan penelitian) 
Sub Judul

Sub Judul

SIMPULAN

DAFTAR PUSTAKA
: Sesuai dengan kebutuhan (tanpa numbering)

: (Berisi simpulan dan saran)

: (Berisi pustaka yang dirujuk dalam uraian naskah

6. Referensi sumber dalam teks artikel ditulis dengan menggunakan side note, contoh: (Jalalluddin, 1991:79); (Taufik, 2005;350); (Hamid dan Madjid, 2011:43). Sementara penulisan daftar pustaka disusun dengan ketentuan. Nama Pengarang. Tahun Terbit. Judul (dicetak miring). Kota Terbit: Nama Penerbit. Contoh: Koentjaraningrat. 2010. Manusia dan Kebudayaan Di Indonesia. Jakarta: Djambatan.

Daftar pustaka hanya memuat pustaka/sumber yang dirujuk dalam uraian dan disusun menurut abjad, tanpa nomor urut.

7. Naskah yang dimuat akan disunting kembali oleh redaksi tanpa mengubah isinya.

8. Naskah yang ditolak (tidak bisa dimuat) akan dikirim kembali ke penulis dengan pemberitahuan tertulis dari redaksi atau alamat email.

9. Penulis yang naskahnya dimuat akan mendapatkan 1 (satu) majalah nomor yang bersangkutan.

10. Contact Person: Treny Hera (085357344704) dan Mainur (081373165553). 


\title{
BUKIT SIGUNTANG DALAM PENGEMBANGAN KONSEP RUANG KOREOGRAFI LINGKUNGAN TARI
}

\author{
Oleh: \\ Rully Rochayati ${ }^{1}$ \\ (Dosen Prodi Pendidikan Seni Pertunjukan FKIP UPGRI Palembang) \\ Eva Dina Chairunisa ${ }^{2}$ \\ (Dosen Prodi Pendidikan Sejarah FKIP UPGRI Palembang) \\ Email: rullyrochayati@univpgri-palembang.ac.id
}

\begin{abstract}
ABSTRAK
Bukit Siguntang salah satu tempat wisata religius merupakan tempat yang sejuk dengan lingkungan yang asri. Selain itu memiliki banyak cerita yang dapat diangkat dalam bentuk-bentuk seni pertunjukan. Tujuannya memberikan satu wacana baru kepada masyarakat tentang konsep keruangan tari yang representatif. Memberikan suatu pemahaman tentang tari dalam wujud yang berbeda yaitu koreografi lingkungan.Metode penelitian adalah diskriptif kualitatif, untuk proses menentukan apakah Bukit Siguntang dapat digunakan sebagai ruang tari menggunakan konsep moving from within Alma M. Hawkins. Berdasarkan hasil penjelajahan ruang Pucuk Rebung lebih sempit dibandingkan dengan Puncak Mahameru Siguntang. Ruang Pucuk Rebung dapat dieksplorasi secara maksimal dengan memanfaatkan tugu, kolam dan pelataran. Sedangkan area Puncak Mahameru Siguntang hanya dapat dieksplorasi pada pelataran, jembatan penghubung dari tiga kolam. Untuk Tangga Sebelah Timur didominasi oleh bebatuan buatan, hasil temuan adalah konsep ruang yang cukup luas dan terpisah-pisah melibatkan penari yang lebih banyak, dengan menempatkan penari dari beberapa tempat strategi dari area.
\end{abstract}

Kata kunci : Bukit Siguntang; pengembangan; ruang koreografi lingkungan

\section{A. PENDAHULUAN}

Palembang sebagai salah satu wilayah bagian dari Sumatera Selatan memiliki beragam budaya dan lokasi wisata. Budaya yang berkembang di Palembang sangat menarik merupakan warisan dari jaman sebelumnya yaitu jaman Sriwijaya. Entah benar atau tidak hingga sekarang secara terus menerus dilakukan penelitian, termasuk pula lokasi bersejarah yang dapat ditemui.
Begitu banyaknya lokasi bersejarah yang ada di wilayah Palembang, tentunya akan sangat menarik apabila dari setiap wilayah atau lokasi bersejarah tersebut dapat dimanfaatkan. Pemanfaatan yang maksimal dari suatu wilayah dapat menarik minat masyarakat untuk datang berkunjung, tidak saja untuk menikmati keindahan alamnya, memahami sejarah dan budayanya bahkan apa yang tersaji dalam lingkungan tersebut dapat 
memberikan nilai-nilai positif bagi masyarakatnya.

Terkait dengan seni budaya, tempat bersejarah tidak saja dapat diteliti berdasarkan kajian sejarahnya tetapi dapat diteliti dari sudut pandang yang berbeda yaitu aspek ruang dimana tempat tersebut berada. Artinya dalam pandangan seni dan budaya suatu tempat bersejarah dapat digunakan sebagai bagian dari suatu kebudayaan masyarakat setempat.

Bukit Siguntang adalah sebuah bukit kecil setinggi 29-30 meter dari permukaan laut yang terletak sekitar 3 kilometer dari tepian sungai Musi dan masuk dalam wilayah kota Palembang, Sumatera Selatan. Secara administratif situs ini termasuk kelurahan Bukit Lama, Kecamatan Ilir Barat I, Palembang (Wikipedia Bahasa Indonesia, Ensiklopedia bebas, id.wikipedia.org/wiki/bukit_Seguntang.dia kses tanggal 02/02/2017, pukul 09.18)

Lokasi ini sangat strategis karena mudah dijangkau, tak jauh dari pusat kota Palembang. Secara fisik Bukit Siguntang merupakan tempat yang sejuk, nyaman, tertata rapi, dan banyak tumbuh-tumbuhan. Dalam konteks sejarah Bukit Siguntang merupakan satu wilayah yang didalamnya terdapat makam raja-raja pada masa kerajaan Sriwijaya. Sampai sekarang Bukit Siguntang adalah tempat yang dikeramatkan. Makam yang ada di area tersebut adalah Radja Segentar Alam, Putri Kembang Dadar, Panglima Bagus Kuning, Panglima Bagus Karang, Putri Rambut Selako, Pangeran Radja Batu api, Panglima Tuan Djundjungan dan panglima Jago Lawang. Menurut cacatan sejarah, Bukit siguntang sejak abad ke-7 menjadi tempat ibadah penganut Buddha. Hal tersebut dibuktikan dengan ditemukannya arca Buddha dengan tinggi mencapai 2,77 meter yang terbuat dari batu granit (www.indonesia kaya.com/jelajah-indonesia, diakses tanggal 02/02/2017, pukul 9.35).

Bukit Siguntang sebagai ruang eksplorasi gerak tari diharapkan dapat memberikan efek positif dan pemahaman kepada masyarakat bahwa ruang gerak tari dapat diwujudkan dan dikembangkan melalui tempat-tempat wisata yang strategis. Penggunaan konsep ruang ini ternyata dapat digali dengan baik dan mampu memacu ideide yang memiliki kebaruan dalam berkarya tari. Eksplorasi ruang dilakukan 
untuk memberikan hal baru bagi sebuah proses penciptaan karya tari.

Permasalahan yang muncul adalah beberapa area tersebut diatas tidak secara maksimal dan kontinyu dieksplorasi. Hasilnya adalah tempat wisata tersebut hanya sekedar menjadi tempat berkunjung saja, dan tidak memiliki sesuatu yang dapat ditonjolkan.

Berangkat dari akar permasalahan tersebut maka penelitian ini mencoba untuk menggali salah satu konsep ruang yang ada di Bukit Siguntang. Tujuan yang akan dicapai adalah mengetahui lokasi Bukit Siguntang sebagai salah satu pengembangan konsep ruang koreografi lingkungan tari, memberikan satu wacana baru kepada masyarakat tentang konsep keruangan tari yang representatif, dan memberikan suatu pemahaman tentang tari dalam wujud yang berbeda yaitu tentang koreografi lingkungan.

Guna memperjelas dan memperkuat penelitian ini digunakan beberapa landasan teori antara lain:

Ingkang kawastanan joged inggih punika ebahing sadaya sarandhuning badhan kasarengan ungeling gangsa (gamelan) katata pikantuk wiramaning gendhing, jumbuhing pasemon kalayan pikajenging joged. Dalam difinisi itu begitu jelas bahwa yang disebut tari adalah seluruh ketrampilan gerak instrumen tubuh manusia (ebahing sadaya sarandhuning badhan), dengan iringan musik tari, ekspresi seluruh tatanan gerakan yang mengandung maksud atau tujuan tari (Hadi Y. S., 2016).

Teori tari ini digunakan sebagai pijakan dasar dalam memahami apa yang disebut dengan tari. Tari dalam berbagai baik tari primitif, tari tradisonal klasik, tradisional kerakyatan, hingga modern pada dasarnya berbicara tentang gerak, iringan musik, ekspresi dari wajah hingga ekspresi gerakan yang mengandung maksud dan tujuan dari tari itu sendiri.

Konsep koreografi lingkungan dalam buku Koreografi Lingkungan Revitalisasi Gaya Pemanggungan dan Gaya Penciptaan Seniman Nusantara, memberikan penegasan bahwa konsep pemanggungan di wilayah timur bermula dari teater lingkungan yang diciptakan oleh Richard Schechner (Martono, Koreografi Lingkungan: Revitaisasi Gaya Pemanggungan dan Gaya Penciptaan Seniman Nusantara, 2012) Sebagai referensi Koreografi 
Lingkungan, memiliki pengertian yaitu teater yang memadukan ritus masyarakat dengan seni, serta menjalin interdisiplin antar bidang seni yang menyerap potensi-potensi yang ada di alam sekitar (lingkungan) untuk memperkaya unsur-unsur pertunjukan. Jelas pertunjukan digelar di luar konvensi auditorium yang memiliki pembatas atau penyekat antara tontonan dengan penonton. Tontonan disajikan di tengah-tengah masyarakat, lengkap dengan lingkungan serta sosial budaya yang menyertai. Semua unsur yang ada disekitar tempat pertunjukan menjadi bagian dari struktur pertunjukan.

\section{Aspek pendukung tari yang} cukup nyata adalah ruang. Konsep ruang tidak dipahami secara nyata saja tetapi juga ruang imajiner. Berpijak pada konsep moderndance mengungkapkan bahwa ruang sekitar anda seperti anda ketahui, adalah tidak kosong sungguhsungguh. Ruang itu penuh molekulmolekul, seperti segala sesuatu dibuat masalah (Cheney, 1999) Teori ruang pun terungkap lewat pendapat $Y$. Sumandiyo Hadi bahwa pemahaman ruang sebagai elemen tari memiliki hubungan dengan kekuatan-kekuatan motor penggeraknya yaitu struktur ritmis dari pola gerakan yang terjadi dalam ruang itu (Hadi y. S., 1996). Dipertegas dengan pendapat dari Alma M Hawkins bahwa semua gerakan yang dilakukan oleh penari terjadi dalam konteks ruang atau tempat. Setiap gerak, sebuah gesture ataupun pola gerak yang lebih rumit, memiliki suatu desain ruang dan tempat yang menjadi bagian integral dari keseluruhan pengalaman estetis (Dibya. 2003:66). Arah dapat dipahami melalui kemana penari itu bergerak dan arah hadap dari badan penari. Arah penari itu bergerak dapat divisualisasikan dengan gerakan berjalan arah depan, belakang, melompat ke kanan, kiri, serong kanan depan, serong kiri depan. Arah yang dilintasi atau dilalui penari ini seringkali disebut dengan pola lantai. Sedangkan arah hadap tubuh seorang penari dapat banyak berbicara untuk mengenali tingkah laku seseorang (Murgiyanto. 1983:23).

Pada perkembangannya di tahun milenium ditandai dengan bergesernya ruang kesenian keluar dari gedung pertunjukan menuju ruang masyarakat dimana saja, bisa di pasar, di stasiun, jalanan dan ruang-ruang yang tidak lazim, karena bila menenggok sejarah bangsa Indonesia 
dari dulu kala ruang keseniannya adalah alam itu sendiri (Martono, Ruang pertunjukan dan Berkesenian, 2012)

\section{B. METODE PENELITIAN}

\begin{tabular}{llrr}
\multicolumn{3}{c}{ Metode penelitian } & yang \\
digunakan adalah & metode & diskriptif \\
kualitatif yang mana & peneliti
\end{tabular}
mendiskripsikan hasil penelitian secara tertulis, sehingga hasil penelitian dapat tersusun secara baik. Bahan penelitian ini tentunya melibatkan data-data hasil observasi wawancara, dokumentasi dan studi pustaka. Melibatkan juga metode penciptaan tari yang berpijak pada teori Alma M.Hawkins yaitu Moving From Within yang terdiri dari merasakan, menghayati, menghayalkan, mengejawantah, dan memberi bentuk.

\section{HASIL DAN PEMBAHASAN}

1. Gambaran Umum Lokasi Penelitian

$\begin{array}{rrr}\text { Bukit } & \text { Siguntang } & \text { secara } \\ \text { administrasif } & \text { termasuk wilayah }\end{array}$
Kelurahan Bukit Lama, Kecamatan Ilir Barat I, Kota Palembang, terletak $5 \mathrm{~km}$ ke arah barat kota Palembang. Bukit Siguntang secara geografis terletak pada ketinggian 26 meter dari permukaan laut, merupakan bentang alam paling tinggi di
Kota Palembang, mempunyai luas 12,8 hektar, (brosur Bukit Siguntang). Secara topografi daerah Bukit Siguntang sangat menonjol. Sebuah bukit yang lebih rendah disusul tanah cekung yang terendam memisahkan lereng timurnya dari segitiga yang sangat kaya akan situs-situs, di sebelah barat dan tenggara terdapat lereng-lereng yang tidak sekeras yang lain akan melandai dalam cekungan berawa-rawa dimana terdapat Talang Kikim pada pusatnya. Lembah Lamidaro masih dapat disusuri dengan perahu seputar Talang Kikim yang hampir bisa dipastikan bahwa dulunya merupakan salah satu jalur perairan untuk menjangkau bukit tersebut dari Sungai Musi yang bermuara di hulu Karang Anyar. Lereng bagian timur Bukit Seguntang dapat melihat seluruh kota Palembang, jauh lebih terjal dan turun menuju lembah kecil tempat Sungai kedukan Bukit/Tatang berada. Di bagian utara, lereng bukitnya tidak turun hingga permukaan air tetapi langsung menjangkau hamparan luas peneplain tersier yang mencuat membentuk tanah dimana sepertinya bisa ditemukan Padang Penjaringan (yang disebut dalam Sejarah Melayu). Lereng barat bukitnya, pada tahun 1979 tidak ada bangunan 
kecuali dusun Tanjung Rawa (salah satu semenanjung yang menuju cekungan tanah di sebelah tenggara bukit), (Coedes, Damais, Kulke, \& Manguin, 2014).

Bukit Siguntang saat ini merupakan daerah wisata yang didalamnya berisi makam raja-raja pada masa Sriwijaya merupakan sebuah area yang sejuk, dipenuhi dengan pepohonan yang rindang, serta beberapa area yang menarik diantaranya adalah:

\section{A. Pucuk Rebung}

Pucuk Rebung memiliki area yang terdiri dari pelataran melingkar yang ditengahnya terdapat kolam dengan diameter kurang lebih 4 meter, tinggi pembatas kolam 1 meter, kedalaman kolam kurang lebih 1,5 meter, dan dibagian tengah berbentuk rebung atau tunas bambu setinggi 4 meter jika diukur dari kedalaman kolam. Lantai pelataran berwarna merah dengan jarijari kurang lebih 2 meter. 4 sudut terdapat tanaman yang jika diperhatikan membentuk sudut seperti bujur sangkar. Pada bagian Pucuk Rebung berwarna emas dan pada bagian bibir pembatas berwarna merah dan warna bebatuan kapur. Area pucuk rebung berada pada sisi kiri jalan berundak menuju pelataran atas. Sisi kanan-kiri, dan belakang dari area tersebut adalah tanah berumput yang tidak rata.

\section{B. Puncak Mahameru}

Puncak Mahameru merupakan sebutan untuk pelataran bagian atas dari Bukit Siguntang (Hasil Wawancara dengan M.Idris, 20 Juni 2019). Secara visual pelataran Puncak Mahameru terdiri atas 3 jalan dari arah yang berbeda untuk memasuki area tersebut. Puncak Mahameru memiliki pelataran berbentuk melingkar 1 meter, 3 kolam bersusun dengan kedalaman setengah meter, bagian tengah kolam terdapat lingkaran dengan lebar setengah meter, serta tangga penghubung dari setiap kolam dengan lebar 1 meter. Menurut hasil wawancara dengan M.Idris tanggal 12 juni 2019, pada masa Buddha Puncak Mahameru merupakan area yang digunakan untuk mensucikan diri oleh kaum Buddhis tersebut. Tiga (3) susunan kolam tersebut merupakan pengejawantahan dari kamadhatu, rupadhatu, arupadhatu. Dijelaskan lebih lanjut bahwa konsep yang ada di area Puncak Mahameru tersebut sangat mirip dengan konsep perancangan arsitektural Barabudur yang sekarang disebut Candi Borobudur. 


\section{Tangga Sebelah Timur}

Salah satu area yang menarik perhatian dan menjadi fokus dari penelitian ini adalah area Tangga Sebelah Timur dimana tangga tersebut merupakan jalur keluar dari Puncak Mahameru Bukit Siguntang. Apabila didiskripsikan Tangga Sebelah Timur merupakan tangga yang di sisi kanan dan kirinya terdapat bebatuan buatan. Bebatuan mulai dari yang kecil hingga besar, dari yang datar hingga berbentuk tidak teratur, dari bentuk bebatuan yang tumpul hingga tajam. Area yang cukup sejuk, terlindungi dengan adanya banyak pepohonan yang sangat lebat.

\section{Pengembangan Konsep}

\section{Ruang Koreografi Lingkungan} Tari

\section{A. Pengembangan Konsep Ruang Tari}

Pada dasarnya pengembangan konsep ruang tari dapat menjangkau secara luas. Artinya sebuah konsep ruang tari tidak hanya terbatas pada panggung prosenium tetapi dapat dilakukan pengembangan ruang yang lebih menarik seperti melibatkan tempattempat wisata yang ada di daerah tersebut salah satunya adalah Bukit Siguntang.
1. Area Pucuk Rebung

Berdasarkan hasil penelitian yang dilakukan pada bulan Juni sampai dengan Agustus 2019 tentang Pucuk rebung sebagai salah satu konsep ruang dapat dieksplorasi sesuai dengan kemampuan pencipta tarinya. Arah hadap yang terfokus pada satu arah yaitu tengah memberikan satu konsep ruang bahwa pada intinya semua ruang memiliki satu fokus arah yaitu tengah. Fokus perhatian penonton pun secara sadar akan menuju titik tengah. Konsep pelataran dengan bentuk melingkar terwujud dengan hadirnya penari di area tersebut. Pada mulanya penari menjadi satu barisan, ketika memasuki area pelataran Pucuk Rebung kemudian membuka menjadi 2 bagian yaitu satu bagian ke sisi sebelah kanan dan sisi sebelah kiri. Pemecahan kedua penari memberikan pilihan pada penonton untuk memilih bagian mana yang akan dilihat.

2. Area Puncak Mahameru Siguntang

Area Puncak Mahameru Siguntang memiliki karakteristik ruang 
yang tidak jauh beda dengan Pucuk Rebung. Konsep pengembangan ruang yang dilakukan adalah memaksimalkan apa yang ada di area tersebut. Bentuk dari setiap pola ruang yang dieksplorasi memiliki bentuk yang berbeda-beda.

Konsep ruang yang ada dari Puncak Mahameru Siguntang ini tidak memiliki variasi pengembangan ruang baik pola lantai maupun formasi penari. Hal ini disebabkan area pelataran yang memiliki lingkar yang cukup luas sehingga jarak antara penari satu dengan yang lainnya sangat jauh. Jarak antara yang ada di atas kolam cukup dekat sehingga penari terlihat sangat rapat. Jika dilakukan pengelompokan dengan membuat pemisahan fokus perhatian melalui pemecahan formasi penari justru tidak menguntungkan bagi karya itu sendiri. Penonton akan disuguhkan dengan kelompok kelompok penari yang sangat berjauhan dan tidak dapat menikmati gerak tari secara maksimal. Selain itu penonton juga tidak dapat menangkap maksud tarinya secara baik dan menyeluruh.

3. Area Tangga Sebelah Timur
Area Tangga Sebelah Timur memiliki area yang cukup luas dan dapat dieksplorasi dengan konsep yang lebih bebas. Konsep tersebut dapat berpijak dari bentuk-bentuk tradisi atau kontemporer. Penjelajahan ruang dimaksimalkan yaitu dengan mengambil berbagai tempat yang dianggap strategis untuk konsep-konsep tari. Pada area ini sangat mungkin dilakukan pengembangan namun dengan berbagai pertimbangan baik dari segi keindahan hingga segi keselamatan dari penari. Konsep keruangan dari bentuk karya tersebut lebih variatif, penari dapat ditempatkan pada ruang-ruang kosong baik ruang datar ataupun naik pada bebatuan. Penari dengan formasi tersebut terkumpul menjadi satu walaupun dalam bermacam-macam variasi level. Namun dasar dari penempatan penari tersebut adalah melihat adanya area sisi sebelah kanan yang tidak memiliki keseimbangan. Artinya ruang yang ada tidak seimbang antara sisi kanan dan sisi kiri. Sisi kiri lebih menonjol dari pada sisi sebelah kanan. Sisi kiri lebih banyak memiliki bentuk bebatuan yang beragam 
dibandingkan dengan sisi sebelah kanan. Penari ditempatkan pada sisi kiri secara penuh dengan mengutamakan eksplorasi gerak dan ruang secara acak. Memanfaatkan bebatuan yang ada untuk disesuaikan dengan kebutuhan gerak yang digunakan.

Pengembangan konsep ruang pada dasarnya dapat diwujudkan secara nyata kedalam bentuk-bentuk keruangan yang ada. Penjelajahan ruang perlu dilakukan secara intensif dan berkelanjutan agar dapat menemukan bentuk-bentuk keruangan yang beragam. Proses penjelajahan ruang yang sebatas pada konsep ruang saja tetapi juga meliputi konsep koreografi.

Konsep koreografi menjadi bagian yang terpenting dan penentu bagai terwujudnya sebuah bentuk tari. Penata tari, pencipta seni tari sangat memerlukan konsep koreografi agar karya yang terwujud dapat menyatu dengan konsep ruang yang diperlukan.

\section{Pengembangan Konsep Koreografi \\ Merujuk pada arti kata pengembangan yaitu proses, cara, pembuatan (kbbi.web.id. diakses 23 Juli 2019, pukul 21.40), maka sebuah}

koreografi hanya dapat terwujud jika didalamnya terdapat konsep yang melibatkan unsur-unsur tari. Proses yang dilakukan seorang pencipta tari tentunya tidak hanya sekedar bergerak tetapi melakukan berbagai hal yang memiliki keterkaitan dengan konsep koreografi itu sendiri. Sebuah koreografi harus memiliki elemen-elemen estetis yaitu gerak, ruang, dan waktu.

Proses yang dilakukan untuk mengetahui pengembangan koreografi adalah dengan menggunakan metode penciptaan tari Moving From Within: A New Method for Dancing Making. Sebuah metode yang lebih memfokus pada proses penemuan gerak hingga pembentukan yang lebih modern dan lebih bebas. Salah satu metode proses kreatif yang bertitik pusat pada diri sendiri. Dalam metode ini (Hawkins, 2003) digambarkan berbagai fase dengan pola merasakan, menghayati, menghayalkan, mengejawantah, dan memberi bentuk. Proses kreatif di dalamnya tercakup lima fase yang perwujudannya dalam koreografi melibatkan kegiatan menyerap, merasakan dalam tubuh, penemuan, elemen-elemen estetik, dan simbolisasi. 
Berpijak dari temuan-temuan tersebut di atas maka konsep koreografi diperlukan untuk memperjelas, memberi batasan tentang bagian-bagian yang harus dapat dijelaskan baik dari ide gagasan hingga bentuk visual dari tari tersebut. Berikut ini konsep koreografi yang digunakan untuk pengembangan konsep ruang yang ada di Bukit Siguntang.

a. Ide Gagasan

Ide gagasan yang digunakan secara keseluruhan adalah bermula dari kehidupan manusia yang menceritakan tentang manusia dari permulaan hingga ahkir dengan mengekploitasi monumen Pucuk Rebung. Konsep ini diambil dari makna dasar Pucuk Rebung yang memiliki filosofi bahwa evolusi bambu dari muda hingga tua, mencerminkan proses kehidupan manusia menuju pribadi yang bermanfaat. Filosofi pucuk rebung dilihat dari bentuk asli dari pucuk rebung itu sendiri yang ketika pucuk rebung muda terbungkus kulit dan menjadi bambu yang terus menjulang ke atas dengan batang besar yang kokoh dan bagian atas tetap meruncing. Bambu yang sangat lentur jika tertiup angin. Kedua, konsep Puncak Mahameru Siguntang, masih menceritakan keadaan tentang manusia tetapi lebih dijabarkan dengan konsep Budhis. Melibatkan cerita manusia di alam Kamadhatu, Rupadhatu, Arupadhatu. Ketiga adalah Tangga Sebelah Timur, ide gagasan yang muncul keadaan manusia yang ada di bumi, dengan segala perilaku, konsep ini dapat diekplorasi dalam bentuk tradisi ataupun dalam konsep modern dengan garap gerak modern pula.

\section{a. Tema Tari}

Tema tari yang digunakan dalam karya tari ini adalah dramatik, artinya semua gagasan yang akan disampaikan lebih terpusat pada sebuah kejadian atau suasana tertentu tanpa menggelar cerita namun alur yang disampaikan terbaca dengan baik oleh penonton. Melihat dari lingkungan sekitar Bukit Siguntang maka tema tari yang digunakan adalah kesempurnaan hidup manusia. Artinya bahwa manusia dari lahir, menjalani kehidupan, hingga kematian, sebenarnya memiliki satu tujuan yaitu meraih kesempurnaan hidup. Kesempurnaan hidup tersebut hanya dapat terwujud ketika manusia menyatu dengan Tuhannya atau dalam konsep Budhist kesempurnaan hidup hanya dapat diraih ketika manusia telah menjalani hidup di 
alam Kamadhatu, Rupadhatu, sehingga dapat sempuna di alam Arupadhatu.

\section{b. Gerak Tari}

Berdasarkan penemuan melalui metode moving from within maka dasar gerak yang digunakan adalah dasar gerak diambil dari beberapa motif gerak tari Palembang antara lain sembah, kecubung, borobudur, siguntang mahameru, menyisir, dan dipadukan dengan beberapa motif gerak tari gaya Yogyakarta yaitu kapang-kapang, timpuh, jengkeng, bersila, nglayang, mbesut, ukel mlumah, gedruk, ngleyek, ngoyok. Hasil eksplorasi yang didapat adalah beberapa ragam kembangan yang digunakan sebagai ragam dasar yaitu: ragam sembah bumi, ragam sembah tengah, ragam sending layang, ragam tawing nyisir, ragam jalan mahameru, ragam ngoyok borobudur, ragam tawing borobudur, ragam tawing kecubung.

\section{Penari}

Jumlah penari turut menentukan terbentuknya suatu karya seni, karena melalui tubuh penari, penata tari, pencipta tari dapat memvisualkan ide gagasannya. Pada karya tari ini melibatkan 10 penari yang terdiri dari 9 penari putri dan 1 penari laki-laki. Dalam konsep Pucuk Rebung penari yang digunakan adalah 9 orang penari putri, sedangkan pada Puncak Mahameru Siguntang dan bebatuan digunakan 9 penari putri dan 1 penari laki-laki. Hal ini disebabkan pola ruang yang ada sangatlah luas sehingga memerlukan penari tambahan sebagai penguat dari karya tersebut.

\section{d. Tata Rias Dan Busana}

Tata rias yang digunakan pada karya tari ini adalah rias cantik atau corective make up, dengan penekanan pada garis-garis wajah sehingga penonton dapat melihat ekspresi penari dengan baik walau dari jarak yang jauh. Busana yang digunakan terdiri dari kain putih, kain batik hitam putih, kebaya putih, kaos hijau, longtorso, selendang putih, korset, gelung, cempako, ikat pinggang.

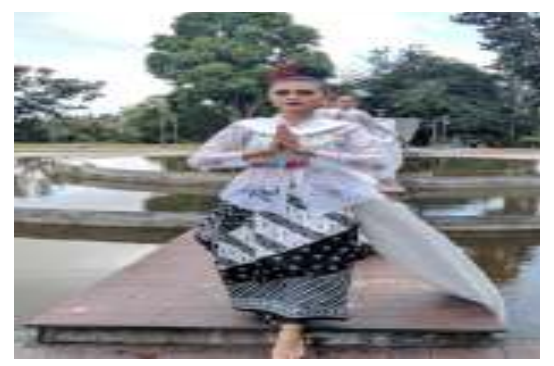

Gambar 1. Perancangan awal tata rias dan busana.Dokumentasi. Sigit AM. (2019) 
e. Musik Iringan Tari

Konsep musik iringan tari yang nantinya digunakan bersifat ilustrasi dengan menekankan pada suasana tenang, khusyuk, agung. Konsep ini tentunya belum sepenuhnya dapat terealisasi dengan baik mengingat terbatasnya waktu penelitian dan penekanan fokus penelitian hanya sebatas pengembangan konsep ruang.

\section{f. Pola Lantai}

Pola lantai pada konsep karya inisangat bervariasi, sehingga pola lantai yangdigunakan membuat karya tari ini tidak monoton. Konsep Pucuk Rebung dan Puncak Mahameru Siguntang cenderung berbentuk lingkaran dan lurus, namun dalam proses lanjutan dapat diolah kembali dengan memanfaatkan arah, level, maka pengembangan pola lantai dapat beragam. Untuk konsep Tangga Sebelah Timur memiliki banyak variasi pola lantai, hal ini dikarenakan lokasi bebatuan yang acak, tidak beraturan, dengan jarak yang beragam.

Bukit Siguntang dengan
berbagai area didalamnya ternyata
mempunyai keunikan yang dapat digali
dan dieksplorasi sehingga menemukan
berbagai hal yang dapat dikembangkan

dan mampu memberikan suasana baru. Konsep pengembangan ruang tari ini merupakan sebuah keinginan agar Bukit Siguntang sebagai area wisata juga memiliki nilai lebih atau nilai tambah agar setiap waktu dapat berkembang sejajar mengikuti kemajuan jaman. Beberapa hal yang diperlukan dalam pengembangan konsep ruang dalam koreografi lingkungan tari yang ada di Bukit Siguntang adalah:

a. Kemampuan seniman dalam hal ini penata tari, pencipta tari. Kemampuan yang harus dimiliki tidak hanya kemampuan bergerak, tetapi kemampuan untuk menginterpretasikan, kemampuan untuk mengembangkan, kemampuan untuk mengekplorasikan, yang semuanya itu berahkir pada kemampuan menata bentuk. Penata tari, pencipta tari, dapat memanfaatkan metode berkarya tari seperti salah satunya Metode Moving From Within. Metode yang menawarkan lima konsep dasar yang dapat dilakukan oleh penata tari, pencipta tari yaitu merasakan, menghayati, menghayalkan, mengejawantah dan pembentukan/ memberi bentuk. 
Dengan metode ini penata tari, pencipta tari dapat mengembangkan konsep-konsep karya tari secara lebih pribadi.

b. Kemampuan yang harus dimiliki oleh penata tari, pencipta tari adalah kemampuan memahami dan mengetahui konsep ruang, baik itu konsep ruang nyata maupun konsep ruang tidak nyata. Dengan pemahaman konsep ruang ini penata tari, pencipta tari dapat menuangkan ide-ide gagasannya dalam ruang tari dan tubuh penari. Penata tari, pencipta tari perlu memahami ada banyak konsep yang tidak dapat divisualkan dengan baik oleh tubuh penari, ada banyak konsep ruang yang tidak dapat menjelaskan dengan baik ide gagasannya. Namun ada juga banyak ide yang dapat divisualkan oleh tubuh penari dan ruang tari. Untuk itu pemahaman konsep ruang nyata dan konsep ruang tidak nyata sangat diperlukan.

c. Kemampuan mengolah karya tari dengan konsep koreografi. Kemampuan ini sangat diperlukan agar karya tari dapat terbaca dengan baik oleh penonton. Melalui konsep koreografi apa yang ingin diungkapkan dari karya tari tersebut dapat tersampaikan dengan baik. Dalam sebuah penataan, penciptaan karya tari yang dibutuhkan tidak hanya gerak, tetapi diawali dengan ide gagasan, kemudian menentukan tema, jumlah penari, tata rias dan busana, musik iringan tari, dan pola lantai. Dalam konsep ini belum dapat terjabarkan dengan baik, artinya semua aspek terbentuknya suatu karya tari belum tersentuh secara maksimal.

Pengembangan konsep ruang yangada di Bukit Siguntang dapat dilakukan dengan baik dan maksimal selama penata tari, pencipta tari mempunyai tiga kemampuan dasar tersebut di atas. Berdasarkan tiga kemampuan dasar di atas maka di area mana pun ruang tari dapat terbentuk dengan baik. Konsep ruang yang kaya maka akan menghasilkan ide gagasan dan gerak yang beragam pula. Tentunya konsep pengembangan ini tidak hanya sebagai ide gagasan perlu ditindak lanjuti secara serius agar area wisata Bukit Siguntang dapat menjadi area wisata yang manarik dan banyak dikunjungi oleh wisatawan. Keterlibatan pemerintah 
menjadi bagian yang paling penting selain keterlibatan pelaku-pelaku seni, juga masyarakat turut memberikan andil walaupun hanya sebagai penonton.

\section{SIMPULAN}

Bukit Siguntang dengan semua keadaan yang ada di sekitarnya, merupakan salah satu aset wisata yang selalu dapat dikembangkan dan digali secara terus menerus. Keterlibatan seni budaya yang ada baik sejarah yang sudah ditorehkan atau dari masyarakat dapat dilibatkan secara aktif. Salah satu yang dapat dilakukan adalah melibatkan bidang seni khususnya tari. Pengembangan konsep-konsep tari yang melibatkan konsep ruang dapat secara serius diwujudkan sehingga Bukit Siguntang selain sebagai tempat wisata juga sebagai ruang tari atau dapat juga disebut studio alam yang menarik.

\section{Daftar Pustaka}

Cheney, G. (1999). Konsep-Konsep Daras Dalam Modern Dance. Yogyakarta: manthili.

Coedes, G., Damais, L. C., Kulke, H., \& Manguin, P. Y. (2014). Kedatuan Sriwijaya. Depok: Komunitas Bambu.

Hadi, y. S. (1996). Aspek-Aspek Dasar Koreografi Kelompok. Yogykarta: Manthili.

Hadi, Y. S. (2016). Seni Pertunjukan dan Masyarakat Penonton. Yogyakarta: Cipta Media.

Hawkins, A. M. (2003). Bergerak Menurut Kata Hati Metoda Baru Dalam Menciptakan Tari. Jakarta: Ford Foundation dan Masyarakat Seni Pertunjukan Indonesia.

Martono, H. (2012). Koreografi Lingkungan: Revitaisasi Gaya Pemanggungan dan Gaya Penciptaan Seniman Nusantara. Yogyakarta: Cipta Media.

Martono, H. (2012). Ruang pertunjukan dan Berkesenian. Yogyakarta: Cipta Media.

https://id.m.wikipedia.org

https://id.m.wikipedia.org

kbbi.web.id.

wikipedia Bahasa Indonesia, Ensiklopedia bebas,id.wikipedia.org/wiki/bukit_Seguntang www.indonesia kaya.com/jelajah-indonesia 